\title{
Retailers in malls: Retailers' preferences for store space in Indian malls
}

Received (in revised form): 28th January 2010

\section{Arpita Khare}

is currently Associate Professor in LDC Institute of Technical Studies, Allahabad. She has a MBA degree in Marketing and DPhil in International Management. Her research interests span over supply chains, retailing, customer relationship management and services marketing. She has authored quite a few research papers in international and national journals.

\section{Sapna Rakesh}

is the principal of the Undergraduate Campus in Institute of Technology \& Science, Mohanagar, Ghaziabad. She gained her MBA degree from Jiwaji University, Gwalior and PhD from Kurukshetra University in Internet marketing. Her current areas of research focus on customer relationship management, brand management and retailing. She has over 14 years of teaching and industry experience and has published papers in international and national journals.

ABSTRACT Organised retailing in the form of malls is poised to develop exponentially in India. Malls are transforming the landscape of Indian retailing and consumers' attitudes towards shopping. The upsurge of mall activity poses a question of how much malls are responsible for generating sales and consequently generating profits. The research was directed at retailers with stores in the malls and deciphering their opinions about what generates consumer traffic and profits in malls. The retailers' selection of malls is driven by the business potential offered by malls. The research was conducted through primary research administered through a structured questionnaire. The findings demonstrate that an assortment of factors is responsible for mall traffic. These may be categorised under entertainment facilities, services, ambience and mall management.

Journal of Retail \& Leisure Property (2010) 9, 125-135. doi:10.1057/rlp.2010.1

Keywords: malls; retailers; ambience; entertainment; mall operators

Correspondence: Arpita Khare LDC Institute of Technical Studies, 9, J.L. Nehru Road, Allahabad, Uttar Pradesh, India

\section{INTRODUCTION}

In recent years India has witnessed a massive expansion in retailing. Malls, which were earlier concentrated only in metropolitan cities are extending their reach to non-metropolitan cities. The investment and growth in malls is primarily driven by changes in the lifestyle of consumers and transition in retailing from unorganised to organised formats. For most consumers malls play a major role in lifestyle (Terblanche, 1999). Messinger and Narasimhan (1997) suggest that 
consumers' choice of retailers is influenced by; assortment of products available, price of the products, transactional convenience and the shopping experience. Lindquist (1973) claims that variety in merchandise; service and location of the store are determinants for customers' choice of stores. The customers' choice of retailing formats is primarily governed by the variety and services offered. Bloch et al (1994) stressed that mall was perceived attractive because of the physical ambience and the entertainment facilities. They state that physical environment affected the emotions of the customers. Retailers envisage huge potential profits and product sales in malls and thus are prepared to pay high rentals for space in malls. Malls try to gain loyalty of the shoppers' by appealing to their social motives and need for variety in the assortments (Solomon, 2002). Malls are also often a central point for community interaction and entertainment, and to attract consumer traffic to the malls, retailers have to fulfill the social and hedonic shopping needs (Tauber, 1972; Holbrook and Hirschman, 1982).

This primary research on mall retailers tries to understand the factors which play a critical role in generating consumer traffic and consequently sales. Most malls are supposed to fulfill the consumers need for personal and social needs (Tauber, 1972; Rintamaki et al, 2006) and therefore to generate mall traffic, it is vital to address these consumer needs. The consumer motives are not only in utilitarian (Babin et al, 1994; Holbrook, 1999) but are also hedonic (Arnold and Reynolds, 2003). Improving facilities and services in malls can be instrumental in drawing consumers to the malls and enhance the overall retail setting (Castaldo and Botti, 2001).

The entertainment facilities provide extra value to the consumers (Kumar and Karande, 2000) and make the shopping experience pleasurable (Jones, 1999). Malls can be profitable if they are able to fulfill the consumers' needs and lure consumers as retailing is an integral part of the social structure of a city; and enhances the social and economic climate (Hernandez and Jones, 2005). Malls that create a suitable appeal for the consumers can become destination attractions in their own right (Ooi and Sim, 2007). The size of malls and the quality of facilities offered can also be influential in drawing consumers to the stores and unfavourable design elements can deter the consumers from visiting the malls (Brown, 1999). The analysis of productivity of malls is an important aspect of retailing (Barros and Alves, 2004) and this puts the pressure on retailers to increase the services and facilities.

This research focused on three attributes of malls, explicitly, mall management, entertainment facilities and services offered in the malls. Through a primary research conducted with the help of structured questionnaire, the study examined the retailers' perspective in renting space in the mall; we intended to consider their satisfaction with mall management in providing the right setting for doing business there. We segregated the various attributes of mall profitability into three segments which were considered vital from the retailers' viewpoint. Retailers rented stores in the malls under the assumption that mall background would enable them increase sales. Also shopping centres have 'magnet' stores (Brown, 1993) which generate more traffic and 
indirectly enable other retailers do more business. Kirkup and Rafiq (1994) state that competition between shopping centres also affects in getting the best brands to open stores in the malls. Traditionally shopping centres had more of departmental stores (Carlson, 1991) but now specialty stores, branded apparel and cinemas are equally important aspects of malls. When selecting a mall in which to open a store, retailers attach some importance to the facilities and space management of the mall. While profit is imperative, consumer traffic is also considered essential by retailers. They consider presence of other retail outlets also while planning to rent space in a shopping centre.

The first section of the article deals with the background information of facilities provided by malls for attracting and encouraging consumers to visit it. The second section deals with research methodology and the third section on findings and discussion. The final section includes managerial implications and suggestions to mall operators in India.

\section{BACKGROUND}

The growth of malls in cities in India has raised an important question as to their viability and whether increased investment in malls would attract adequate number of consumers. In the past few years there has been a tremendous rise in interest in the establishment of malls. This growth has been fuelled by investments in organised retailing, changes in the retail formats, increased flow of FDI in retailing and increased income levels of consumers. Malls originally served as growth catalysts in the suburbs (Stockil, 1972) and were responsible for changing the notion of shopping. The popularity and expansion of malls was in the form of urban entertainment centres with restaurants and cinemas (Kooijman, 2002), open air lifestyle centres with upscale specialty and branded stores (Hazel, 2005) and hybrids (Monroe, 2003). Many studies have focused on malls as being a part of consumers' leisure activities (Jackson, 1991) and being related to entertainment (Wakefield and Baker, 1998; Jones, 1999). The ambience, design and layout of the malls evoke varying degrees of emotional reaction from the customers (Baker et al, 1992; Bitner, 1992; Babin and Attaway, 2000) and motivate them to spend time in the mall locale. Donovan and Rossiter (1982) posit that environment has an impact on consumer's emotions and can be a driver to retail performance.

The mall operators and retailers are faced with the growing challenge of creating shopping environment which would create a positive influence on the consumers' shopping behaviour (Babin and Attaway, 2000; Stoel et al, 2004; Laroche et al, 2005). The rise of malls in India, as centres of community and social activity has a profound impact on selling and retailing. Retailers vie for acquiring space in malls in the hope that the ambience and facilities of the malls would give a competitive advantage to their stores and wares. Malls as centres of family outings are fast catching the imagination of the Indian consumers. The glamour of malls with sparkling environs and multiplicity of stores is considered a respite in the hectic metropolitan lifestyles. The shopping centres are progressively spending resources to make their malls striking destinations and different from competitors through image and store 
brand communications which supposedly draws consumers to the malls improving foot traffic and stimulating sales (LeHew and Fairhurst, 2000; Parsons and Ballantine, 2004). The idea of shopping has expanded to include an assortment of facilities under one roof wherein entertainment takes a predominant space. The facilities at the shopping centre encompass all kinds of outlets ranging from bookstores, beauty salons, restaurants, medical and grocery stores, stores for branded clothes and shoes, beauty and fashion accessories and products, furniture and home products and amusement centres for kids. This kind of experience is devoid of the negative facets of traffic congestion and security issues (Bloch et al, 1994; Roulac, 1994; Erkip, 2003).

Hypothesis 1: Efficient mall management is responsible for retailer satisfaction towards the malls.

The emphasis on drawing more consumers to the malls is driven by the intrinsic desire of survival. Even though malls are considered glamorous and spending time in malls is an elite behaviour, many consumers do not shop in the malls. They are considered more as social hubs for spending Sundays with the family or friends by just doing 'window shopping'. Malls represent a lifestyle and encourage consumers to relax (Guidry and Montero, 2005) in the comfortable milieu. Another reason is that too many malls have increased the competition among mall operators and each wants to get the best brands and entertainment facilities in their malls so that they may be a major crowd puller. Mall managers initiate public relations building promotional activities for attracting consumers to the stores and thereby contributing to profits and sales (Kirkup and Rafiq, 1999). Research posits that promotional activities encourage mall visits (Folkes and Wheat, 1995; Smith and Sinha, 2000; Parsons and Ballantine, 2004) and help in differentiating it from its competitors. Conventionally, the focus of mall managers was on promotional activities to draw consumers to the stores (Cardona, 2003; Parsons, 2003; Parsons and Ballantine, 2004), but now it also includes generating sales. The malls promotional activities combine product and service benefits (Castaldo and Premazzi, 2001) thus mixing the product related factors with emotional aspects.

Various factors may be considered vital for mall profitability. Some attributes explored by De Juan (2004) were distance of the retail location from home, store image, and availability of merchandise as being responsible for understanding consumer loyalty and patronage to malls. It is also affected by the consumers' perception about utility and value of retail locations (Fotheringham and O'Kelly, 1989). Tangible and intangible attributes were both important as consumers are motivated unvaryingly by the variety and number of stores as by the design and parking facilities (Bearden, 1977; Castaldo and Botti, 2001; Yan and Eckman, 2009). Research states that a variety of factors affect the success of malls; it may not be only related to the location of malls (Ownbey et al, 1994), store atmospherics (Babin and Attaway, 2000), size and quality of facilities (Brown, 1999). The type of stores and image of the malls is also accountable for attracting consumers to the stores. 
Mall managers have to analyse the significant factors influencing consumers' loyalty and according plan the stores and assortment mix. Malls are preferred for various attributes such as price, layout, convenience, merchandise offered, appearance, services and facilities (Downs, 1970; Lumpkin et al, 1986; Castaldo and Botti, 2001; Coye, 2004; Keng et al, 2007). Accordingly, for a mall to be profitable the functional aspects have to be integrated with emotional aspects of shopping. Mathwick et al, (2001, p. 40) state that to be successful retailing had to be transformed into interactive environments where the service aspects should be given priority. The personal interaction and the physical ambience play a crucial role in consumer purchase intentions (Holbrook, 1994). The enhancement of services and facilities in shopping centres may lead to increased convergence of foot traffic.

Hypothesis 2: Ambience and the services offered in the malls are responsible for retailer satisfaction towards the malls.

The type of services and stores are responsible for luring the consumers to the malls. If the malls house major brands, departmental stores, reflects an image of the quality of merchandise (Chebat et al, 2006), provides adequate facilities like parking space, restaurants, gaming area, sitting area for the elderly and kids, cinema halls and specialty stores; the consumer would prefer to frequent the mall. Kirkup and Rafiq (1994) have analysed the tenants' occupancy in mall affected the consumers behaviour to shop in that mall. The malls offering a range of stores like, department stores, apparel stores, and entertainment and leisure facilities (Abratt et al, 1985; McGoldrick and Thomson, 1992; Prendergast et al, 1998) may have a lucrative business. Research shows that consumers are also attracted to malls by an 'anchor tenants' name' (Finn and Louviere, 1996; Konishi and Sandfort, 2003; Ibrahim and Galven, 2007) so mall operators attempt to lease space to popular brands and restaurants. The impression of the mall is based upon the types of stores and the entertainment facilities, 'a combination of tangible or functional factors and intangible or psychological factors' (Hook, 1989). Malls owing to their architectural design, layout and ambience and 'synergies among retailing, eating and entertaining' (Beyard et al, 2001; De Nisco and Napolitano, 2006) become tourist destinations (Ooi and Sim, 2007). In India, some malls are perceived to be offering novel and latest wares coupled with best facilities for parking and eateries.

Hypothesis 3: Entertainment facilities offered in the malls are responsible for retailer satisfaction towards the malls.

Retailing in India is growing substantially and there has been upsurge of mall-related investment with malls being considered as centres for lucrative business opportunities. As shown by Jones and Meghraj (2007), most malls are being built in areas where the mall density is already high. Based on our preliminary research in the National Capital Region in the 
vicinity of Delhi, we found that in most of the malls, the retail outlets are having the identical brands, services and specialty stores. The stores being analogous and common, it becomes exigent to offer differentiated products or experiences to attract the consumers. India is about to be a ground of around 600 malls by 2010 (Jones and Meghraj, 2007) and this is bound to raise the issue of survival for many retailers having stores in the malls.

\section{METHODOLOGY}

The research was carried out in a tightly controlled mall survey. The questionnaire was addressed to mall retailers. The focus was retailers having outlets in malls in and around National Capital Region in India (comprising of cities of Gurgaon, Noida, Ghaziabad, Faridabad and the capital city of Delhi). Total 32 malls were covered and the sample size was 300 retailers. However, we were able to get only 224 complete questionnaires which could be used for the final analysis. Graduate marketing students handled the fieldwork and were motivated by being provided travelling expenses for data collection. Retailers were asked to fill in a structured questionnaire which they had to indicate their agreement on a five-point Likert-type scale (1 - strongly disagree, 5 - strongly agree). The questionnaire items were 34 , comprising of dimensions related to ambience and services provided in the malls, entertainment facilities provided in the malls and mall management. We assumed that presence of these attributes would be responsible for generating greater satisfaction in the minds of the retailers' regarding having a store in the mall. The stores in the malls were classified under six categories: food, garments/apparels, electronics, accessories, household items and others. The retailers were asked whether they were satisfied by the availability of the facilities in the malls and which factors they considered important for generating sales.

\section{FINDINGS AND DISCUSSION}

As a reliability test, we computed Cronbach's $\alpha$ value for the scale items. The $\alpha$ value for the questionnaire items was 0.768 . The questionnaire items could be segregated into three dimensions, related to mall management, entertainment facilities provided, ambience and services offered by malls. Correlations between the three dimensions and how far they were responsible for generating retailer satisfaction was tested. The results of correlation are stated in Table 1.

The results show that correlation is high between retailer satisfaction and entertainment facilities $(P=0.000$ which is significant at 0.01 level $)$ and for ambience and services $(P=0.000$ which is significant at 0.01 level). Retailers did not perceive mall management as being important variable in generating mall traffic. The research findings are consistent with earlier researches (Holbrook, 1994; Prendergast et al, 1998; Beyard et al, 2001; Castaldo and Botti, 2001; Coye, 2004; Keng et al, 2007) which state that physical ambience, entertainment facilities and services such as parking, restaurants, and amusement centres for kids and sitting spaces were responsible for increased footfall in the malls. The retailers also considered that for malls to be profitable it was imperative to have 
Table I: Correlations between mall management, entertainment facilities, services provided and retailer satisfaction towards malls

\begin{tabular}{lc}
\hline Variables related to malls & Retailer satisfaction \\
\hline Mall management & \\
Pearson correlation & 0.127 \\
Sig. (two-tailed) & 0.057 \\
$N$ & 224 \\
Entertainment facilities/services & \\
Pearson correlation & $0.372^{* *}$ \\
Sig. (two-tailed) & 0.000 \\
$N$ & 224 \\
Ambience and services & \\
Pearson correlation & $0.328^{* *}$ \\
Sig. (two-tailed) & 0.000 \\
$N$ & 224 \\
** Correlation is significant at the 0.01 level (two-tailed).
\end{tabular}

** Correlation is significant at the 0.01 level (two-tailed).

Table 2: Retailers' choice for malls: Multiple regression analysis

\begin{tabular}{|c|c|c|c|c|c|c|}
\hline \multicolumn{2}{|c|}{ Independent variables } & \multicolumn{2}{|c|}{$\begin{array}{l}\text { Unstandardized } \\
\text { coefficients }\end{array}$} & \multirow{2}{*}{$\begin{array}{c}\begin{array}{c}\text { Standardized } \\
\text { coefficients }\end{array} \\
\text { Beta }\end{array}$} & \multirow[t]{2}{*}{$t$} & \multirow[t]{2}{*}{ Sig. } \\
\hline & & B & SE & & & \\
\hline \multirow[t]{4}{*}{1} & (Constant) & -0.254 & 0.717 & - & -0.354 & 0.724 \\
\hline & Mall management & -0.009 & 0.016 & -0.040 & -0.596 & 0.552 \\
\hline & $\begin{array}{l}\text { Entertainment facilities/ } \\
\text { services }\end{array}$ & 0.091 & 0.022 & 0.287 & 4.098 & 0.000 \\
\hline & Ambience and services & 0.047 & 0.016 & 0.212 & 2.946 & 0.004 \\
\hline
\end{tabular}

Dependent variable: Retailer satisfaction with a mall. $N=224$. Significant at 0.01 level.

a variety of stores and include entertainment facilities. They preferred to have stores in malls which had good ambience (Yan and Eckman, 2009), were spacious, and housed variety of branded stores (Kirkup and Rafiq, 1994; Ibrahim and Galven, 2007), restaurants, Cineplex and amusement centres. These were considered as key elements when consumers' selected a mall. Presence of these facilities were perceived as being responsible for mall patronage and providing more value to them (Castaldo and Botti, 2001).

To understand the preference of retailers towards malls, we ran a Multiple Regression analysis. We wanted to understand retailers' reasons for preferring a mall to open a store. The results are shown in Table 2.

The analysis shows that presence of entertainment facilities in malls were considered significant attribute for the retailers preferring a mall for stores. The results show that $t$ value is 4.098 and the $P=0.000(P<0.01)$ which is significant at 0.01 level. The ambience and services offered by malls were also considered critical factors by retailers $(t=2.946$ and $P=0.004$ which is significant at 0.01 level). This is consistent with our earlier findings that retailers considered entertainment and ambience as 
Table 3: ANOVA between the different categories of retailers

\begin{tabular}{lccccc}
\hline & Sum of squares & df & Mean square & $F$ & Sig. \\
\hline $\begin{array}{l}\text { Mall management } \\
\text { Between groups }\end{array}$ & 51.593 & 5 & 10.319 & 0.572 & 0.721 \\
$\quad$ Within groups & 3913.440 & 217 & 18.034 & - & - \\
$\quad$ Total & 3965.032 & 222 & - & - & - \\
Entertainment facilities/services & & & & & \\
$\quad$ Between groups & 16.767 & 5 & 3.353 & 0.330 & 0.894 \\
$\quad$ Within groups & 2203.229 & 217 & 10.153 & - & - \\
$\quad$ Total & 2219.995 & 222 & - & - & - \\
$\begin{array}{l}\text { Ambience and services } \\
\quad \text { Between groups }\end{array}$ & 106.355 & 5 & 21.271 & 1.035 & 0.398 \\
$\quad$ Within groups & 4460.038 & 217 & 20.553 & - & - \\
$\quad$ Total & 4566.393 & 222 & - & - & - \\
\hline
\end{tabular}

vital factors for success of a mall. They were willing to pay a high rent for having store space in malls which were having attractive ambience and multiple entertainment facilities. Retailers preferred stores in malls which had good ambience (Yan and Eckman, 2009), architectural design, layout and offering multiple services at one place (Lumpkin et al, 1986; McGoldrick and Thomson, 1992; Coye, 2004; De Nisco and Napolitano, 2006). To understand whether there existed indifferences in the perception of different types of retailers (food, garments/apparels, electronics, accessories, household items and others), we applied ANOVA. The results are shown in Table 3.

The results show that perceptions of the different product retailers are similar. There were no significant differences between the groups. The $F(5,217)=0.572, P=0.721$, for mall management; $F(5,217)=$ $0.330, P=0.894$ for entertainment facilities/services; and $F(5,217)=1.035$, $P=0.398$ for ambience and services. All the results are insignificant, implying there existed no difference in the opinion of the retailers towards the attributes of malls.

\section{CONCLUSION AND MANAGERIAL IMPLICATIONS}

Two important implications are apparent from the research; one is related to retailers' choice for opening a store in the malls and second related to drawing consumers to visit the malls so as to increase the profitability of the malls. Retailers' perceptions regarding productivity of the mall are significant in enticing them to open stores. From the retailers' perspective, the malls which convey 'suitable ambience', housing variety of stores and 'anchor stores' (Finn and Louviere, 1996; Konishi and Sandfort, 2003) are considered lucrative business venues. Markin et al (1976) had suggested that environmental cues permeate the retail environment; our research also has similar implications.

Retailers expect the mall management to endow the malls with relevant cues in form of stores of branded apparel, cinema halls, dining area and recreational centres for drawing consumers to the malls. The absence of emotional or intangible elements in a shopping centre directly affects its performance. While planning the layout, design and ambience of 
malls, space should be allocated to variety of activities and stores, so that consumer has varied options at one place. Parsons and Ballantine (2004) stated that promotional activities would also improve the performance and lure consumers to the shopping centres. Retailers were of the view that if consumers visited the mall for watching a film or just for spending time, there is a probability that they would also shop. Thus, the retailer placed high relevance to the presence of Cineplex and anchor stores for pulling consumers to stores and increasing the footfall. Most retailers perceived entertainment as being foremost for increased consumers' visits. This is similar to the assertion of other researchers (Talpade and Hayes, 1997; Arnold and Reynolds, 2003; Sit et al, 2003), wherein they state 'entertainment is pivotal to shopping centres' because it makes shopping fun and beguiles consumer patronage. The shopping centres should thus transmit an image of providing parking facilities, easy accessibility, elevators, clean ambience with lot of space for walking, spacious dining areas and recreational facilities. The mall managers should take steps to ensure that the malls communicate the appropriate image not only in the minds of the consumers but also the retailers. This would enable the malls battle against completion and also charge a high rent for store space from the retailers. Retailers are willing to pay a high rent for acquiring space in malls that are able to generate more consumer traffic.

\section{REFERENCES}

Abratt, R., Fourie, J.L. and Pitt, L.F. (1985) Tenant mix: The key to a successful shopping center. The Quarterly Review of Marketing 15(1): 19-26.

Arnold, M.J. and Reynolds, K.E. (2003) Hedonic shopping motivations. Journal of Retailing 79(1): 77-95.

Babin, B.J. and Attaway, J.S. (2000) Atmospheric affect as a tool for creating value and gaining share of customer. Journal of Business Research 49: 91-99.

Babin, D.J., Darden, W.R. and Griffin, M. (1994) Work and/or fun? Measuring hedonic and utilitarian shopping value. Journal of Consumer Research 20(4): 644-656.

Baker, J., Levy, M. and Grewal, D. (1992) An experimental approach to making retail store environmental decisions. Journal of Retailing 68(Winter): 445-460.

Barros, C.P. and Alves, C. (2004) An empirical analysis of productivity growth in a Portuguese retail chain using Malmquist productivity index. Journal of Retailing and Consumer Services 11(5): 269-278.

Bearden, W.O. (1977) Determinant attributes of store patronage: Downtown versus outlying shopping centers. Journal of Retailing 53(2): 15-22.

Beyard, M.D., Braun, R.E., McLaughlin, H., Philips, P.L. and Rubin, M.S. (2001) Developing Retail Entertainment Destinations. Washington DC: Urban Land Institute.

Bitner, M.J. (1992) Servicescapes: The impact of physical surroundings on customers and employees. Journal of Marketing 56(April): 57-71.

Bloch, P., Ridgway, N. and Dawson, S. (1994) The shopping mall as consumer habitat. Journal of Retailing 70(1): 23-42.

Brown, M.G. (1999) Design and value: Spatial form and the economic failure of a mall. Journal of Real Estate Research 17(1/2): 189-226.

Brown, S. (1993) Post modern marketing. European Journal of Marketing 27(4): 19-34.

Cardona, M.M. (2003) Branding the mall: Mills taps NY shop and boosts budget. Advertising Age 74(7): 7.

Carlson, H.J. (1991) The role of the shopping centre in US retailing. The International Journal of Retail \& Distribution Management 19(6): 13-20.

Castaldo, S. and Botti, C. (2001) Lo shopping esperienziale. In: S. Castaldo (ed.) Retailing \& Innovazione. Milano, Italy: Egea, pp. 185-213.

Castaldo, S. and Premazzi, K. (2001) Le strategie di posizionamento. In: S. Castaldo (ed.) Retailing \& Innovazione. Milano, Italy: Egea, pp. 39-87. 
Chebat, J.-C., Sirgy, M.J. and St-James, V. (2006) Upscale image transfer from malls to stores: A self-image congruence explanation. Journal of Business Research 59: 1288-1296.

Coye, R.W. (2004) Managing customer expectations in the service encounter. International Journal of Service Industry Management 15(1): 54-71.

De Juan, M.D. (2004) Why do people choose the shopping malls? The attraction theory revisited: A Spanish case. Journal of International Consumer Marketing 17(1): 71-96.

De Nisco, A. and Napolitano, M.R. (2006) Entertainment orientation of Italian shopping centers: Antecedents and performance. Managing Service Quality 16(2): 145-166.

Donovan, R.J. and Rossiter, J.R. (1982) Store atmosphere: An environmental psychology approach. Journal of Retailing 58(Spring): 34-57.

Downs, R.M. (1970) The cognitive structure of an urban shopping centre. Environmental Behaviour 2: 13-39.

Erkip, F. (2003) The shopping mall as an emergent public space in Turkey. Environment and Planning A 35: 1073-1093.

Finn, A. and Louviere, J. (1996) Shopping centre image, consideration and choice: Anchor store contribution. Journal of Business Research 35(3): 241-252.

Folkes, V. and Wheat, R.D. (1995) Consumers' price perceptions of promoted products. Journal of Retailing 71(3): 317-328.

Fotheringham, A.S. and O'Kelly, M.E. (1989) Spatial Interaction Models: Formulations and Applications. Dordrecht, the Netherlands: Kluwer.

Guidry, K. and Montero, T. (2005) Lifestyle centres: The de-malling of consumerism. Real Estate Review 34(1): 5-16.

Hazel, D. (2005) New lease on lifestyle. Chain Store Age 81(11): 126-128.

Hernandez, T. and Jones, K. (2005) Downtowns in transition: Emerging business improvement area strategies. International Journal of Retail \& Distribution Management 33(11/12): 789-805.

Holbrook, M.B. (1994) The nature of customer value: An axiology of services in the consumption experience. In: R.T. Rust and R.L. Oliver (eds.) Service Quality: New Directions in Theory and Practice. Newbury Park, CA: Sage.

Holbrook, M.B. (1999) Introduction to Consumer Value', Consumer Value: A Framework for Analysis and Research. London: Routledge Kegan Paul.

Holbrook, M.B. and Hirschman, E.C. (1982) The experiential aspects of consumption: Consumer fantasies, feelings and fun. Journal of Consumer Research 9(2): 132-140.

Hook, S. (1989) Development of the store image construct: A review of literature from 1958 to the present. In: P. Bloom et al (eds.) Enhancing Knowledge Development in Marketing. Chicago, IL: American Marketing Association, p. 99.

Ibrahim, M.F. and Galven, T.W.R. (2007) New age retail tenants: A new phenomenon. Journal of Retail \& Leisure Property 6(3): 239-262.

Jackson, E.L. (1991) Shopping and leisure: Implications of west Edmonton mall for leisure and for leisure research. Canadian Geographer 35(3): 280-287.

Jones, M.A. (1999) Entertaining shopping experience: An exploratory investigation. Journal of Retailing and Consumer Services 6(1): 129-139.

Jones, L. and Meghraj, L. (2007) Jones Lang Lasalle Meghraj identifies 'India 50' - The emerging cities for retail activity. 29 June, http://www.accessmylibrary.com/coms2/summary_ 0286-31762360_ITM, accessed 23 December 2009.

Keng, C.-J., Huang, T.-L., Zheng, L.-J. and Hsu, M.K. (2007) Modeling service encounters and customer experiential value in retailing - An empirical investigation of shopping mall customers in Taiwan. International Journal of Service Industry Management 18(4): 349-367.

Kirkup, M.H. and Rafiq, M. (1994) Managing tenant mix in new shopping centres. International Journal of Retail and Distribution Management 22(6): 29-37.

Kirkup, M.H. and Rafiq, M. (1999) Marketing shopping centres: Challenges in the UK context. Journal of Marketing Practice: Applied Marketing Science 5(5): 119-133.

Konishi, H. and Sandfort, M.T. (2003) Anchor stores. Journal of Urban Economics 53: 413-435.

Kooijman, D. (2002) A third revolution in retail? The Dutch approach to leisure and urban entertainment. Journal of Retail and Leisure Property 2(3): 214-229.

Kumar, V. and Karande, K. (2000) The effect of retail store environment on retailer performance. Journal of Business Research 49(2): 167-181.

Laroche, M., Teng, L., Michon, R. and Chebat, J.-C. (2005) Incorporating service quality into consumer mall shopping decision making: A comparison between English and French Canadian consumers. Journal of Services Marketing 19(3): 157-163.

LeHew, M.L.A. and Fairhurst, A.E. (2000) US shopping mall attributes: An exploratory investigation of their relationship to retail productivity. International Journal of Retail \& Distribution Management 28(6): 261-279. 
Lindquist, J.D. (1973) Meaning of image. Journal of Retailing 50: 29-38.

Lumpkin, J.R., Hawes, J.M. and Darden, W.R. (1986) Shopping patterns of the rural consumers: Exploring the relationship between shopping orientations and outshopping. Journal of Business Research 14: 63-81.

Markin, R.J., Lillis, C.M. and Narayana, C.L. (1976) Social psychological significance of store space. Journal of Retailing 52(Spring): 43-54.

Mathwick, C., Malhotra, N. and Rigdon, E. (2001) Experiential value: Conceptualization, measurement and application in the catalog and Internet shopping environment. Journal of Retailing 77(1): 39-56.

McGoldrick, P and Thomson, M. (1992) Regional Shopping Centres. Aldershot, UK: Avebury.

Messinger, P.R. and Narasimhan, C. (1997) A model of retail formats based on consumers' economizing on shopping time. Marketing Science 16(1): 1-23.

Monroe, M.C. (2003) Not just malls, but 'alls'. National Real Estate Investor 45(12): 54.

Ooi, J.T.L. and Sim, L.-L. (2007) The magnetism of suburban shopping centres: Do size and Cineplex matter? Journal of Property Investment \& Finance 25(2): 111-135.

Ownbey, K.L., Davis, K. and Sundel, H.H. (1994) The effect of location variables on the gross rents of neighborhood shopping centers. Journal of Real Estate Research 9(1): 111-123.

Parsons, A.G. (2003) Assessing the effectiveness of shopping mall promotions: Customer analysis. International Journal of Retail and Distribution Management 32(10): 458-464.

Parsons, A.G. and Ballantine, P.W. (2004) Market dominance, promotions, and shopping mall group performance. International Journal of Retail and Distribution Management 31(2/3): $74-80$.

Prendergast, G., Marr, N. and Jarratt, B. (1998) Retailers' views of shopping centres: A comparison of tenants and non-tenants. International Journal of Retail \& Distribution Management 26(4): $162-171$.

Rintamaki, T., Kanto, A., Kuusela, H. and Spence, M.T. (2006) Decomposing the value of department store shopping into utilitarian, hedonic and social dimensions - Evidence from Finland. International Journal of Retail \& Distribution Management 34(1): 6-24.

Roulac, S.E. (1994) Retail real estate in the 21st century: Information technology+time consciousn ess+unintelligent stores=intelligent shopping? Not!. Journal of Real Estate Research 9(1): $125-150$.

Sit, J., Merriless, B. and Birch, D. (2003) Entertainment-seeking shopping centre patrons: The missing segments. Journal of Retail \& Distribution Management 31(2): 80-94.

Smith, M.F. and Sinha, I. (2000) The impact of price and extra product promotions on store preference. International Journal of Retail \& Distribution Management 28(2): 83-92.

Solomon, M.R. (2002) Consumer Behaviour, 5th edn. Upper Saddle River, NJ: Prentice Hall.

Stockil, P. (1972) The Mall. In: C. Darlow (ed.) Enclosed Shopping Centres. London: Architectural Press, pp. 52-62.

Stoel, L., Wickliffe, V. and Lee, K.H. (2004) Attributes beliefs and spending as antecedents to shopping value. Journal of Business Research 57: 1067-1073.

Talpade, S. and Hayes, J. (1997) Consumer shopping behaviour in malls with large scale entertainment centers. Mid-Atlantic Journal of Business 33(2): 153-162.

Tauber, E.M. (1972) Why do people shop? Journal of Marketing 36(4): 46-49.

Terblanche, N.S. (1999) The perceived benefits derived from visits to a super regional shopping centre: An exploratory study. South Africa Journal of Business Management 30(4): 141-146.

Wakefield, K.L. and Baker, J. (1998) Excitement at the mall: Determinants and effects on shopping response. Journal of Retailing 74(4): 515-539.

Yan, R.-N. and Eckman, M. (2009) Are lifestyle centres unique? Consumers' perceptions across locations. International Journal of Retail and Distribution Management 37(1): 24-42. 